\title{
Note du rédacteur
}

Après quatre années comme co-rédacteur et trois années comme rédacteur principal de la Revue canadienne de linguistique, ce numéro de mars 2016 marque la fin de mon mandat. Je passe le flambeau à Elizabeth Cowper, notre nouvelle rédactrice, que je tiens à remercier pour son excellent travail en tant que co-rédactrice depuis trois ans. Je tiens également à remercier Brandon Fry, l'assistant de la revue, Christina Thiele, notre typographe, Réjean Canac-Marquis, le rédacteur des notules, ainsi que Heather Newell, la rédactrice des comptes rendus.

Ce numéro marque le début d'une nouvelle ère pour la Revue canadienne de linguistique. En effet, la revue est désormais publiée par Cambridge University Press. Je remercie Melissa Good à Cambridge University Press et tous les membres du Comité exécutif de l'Association Canadienne de linguistique pour leur patience durant les négociations. Je tiens d'ailleurs à profiter de cette occasion pour remercier AnneMarie Corrigan et son équipe à University Toronto Press.

Ce fut un privilège et un plaisir de travailler comme rédacteur pour une revue qui est l'une des plus vieilles au Canada dans les sciences sociales et les humanités et qui continue à contribuer de manière significative au rayonnement de la linguistique dans le monde.

Éric Mathieu

Université d'Ottawa emathieu@uottawa.ca 


\section{Note from the Editor}

After four years as co-editor and three years as editor of the Canadian Journal of Linguistics, this issue marks the end of my term. I now pass the torch to Elizabeth Cowper, our new editor, and thank her for her excellent work as co-editor over the last three years. I am also very grateful to Brandon Fry, editorial assistant, Christina Thiele, our typesetter, Réjean Canac-Marquis, squibs editor, and Heather Newell, book review editor.

This issue marks the beginning of a new era for the Canadian Journal of Linguistics, which henceforth will be published by Cambridge University Press. I thank Melissa Good, of Cambridge University Press, as well as all of the members of the Executive Committee of the Canadian Linguistic Association for their support and patience during the negotiations. I would also like to take this opportunity to thank Anne-Marie Corrigan and her team at the University of Toronto Press.

It has been a privilege and a pleasure to serve as editor of one of the oldest Canadian journals in the humanities and social sciences - a journal that continues to make a significant contribution to the growth of linguistics in the global context.

Éric Mathieu University of Ottawa emathieu@uottawa.ca 